\title{
KEMAMPUAN BERCERITA PADA ANAK USIA 5 TAHUN: KAJIAN PSIKOLINGUISTIK
}

\section{ABILITY TO TELL A STORY IN A 5-YEAR OLD CHILD: PSYCHOLINGUISTIC STUDY}

\author{
${ }^{1}$ Mia Nur Aprilia, ${ }^{2}$ Nuryani \\ 1,2Universitas Islam Negeri Syarif Hidayatullah Jakarta \\ 1miaaprilia1@gmail.com, ${ }^{2}$ nuryani@uinjkt.ac.id
}

\begin{abstract}
Abstrak
Penelitian ini bertujuan untuk mendeskripsikan kemampuan bercerita pada anak usia 5 tahun dengan dilihat dari kajian psikolinguistik. Saat anak berusia 5 tahun, bahasa untuk berkomunikasi mulai berfungsi dan menghasilkan kalimat sesuai kemampuan anak tersebut. Pada periode diferensiasi, anak usia 5 tahun dianggap memperoleh bahasa ibu mereka dalam aturan tata bahasa dasar orang dewasa. Metode yang digunakan dalam penelitian ini menggunakan metode kualitatif. Metode pengambilan data melalui dialog dengan subyek penelitian anak berusia 5 tahun. Teknik pengambilan data dilakukan dengan teknik percakapan, direkam lalu dicatat. Kegiatan tersebut dilakukan untuk mendapatkan data catatan secara lisan dari subyek penelitian tersebut. Hasil penelitain ini menunjukkan bahwa pola kalimat pada anak usia 5 tahun dipengaruhi oleh lingkungan dan bahasa Ibu.
\end{abstract}

Kata Kunci: Kemampuan Bercerita, Diferensiasi, Bahasa Ibu, 5 tahun.

\begin{abstract}
This study aims to determine the ability to tell stories to children aged 5 years obtained from several questions asked to the child. When a child is 5 years old, the language function for communication starts to function and produces sentences according to the child's ability. At the age of 5 years is considered to be a period of differentiation, where children have obtained their mother tongue in basic adult grammar rules. The method used in this study uses qualitative methods. The method of collecting data through dialogue with research objects collected came from a 5-year-old child who lives in Gunung Putri, Bogor. The data collection technique was carried out using conversation techniques, recorded and recorded to obtain verbal data from the research object. The results of this study indicate that sentence patterns in children aged 5 years are influenced by the environment and mother tongue.
\end{abstract}

Keywords: Story Ability, Differentiation, Mother Language, 5 years.

\section{PENDAHULUAN}

Bahasa dan manusia tidak dapat dipisahkan, karena keduanya berkembang secara bersamaan. Seiring sempurnanya pertumbuhan fisik, maka perkembangan bahasa yang digunakan semakin baik, kecuali sejak bayi baru lahir mengalami cacat fisik. Bahasa adalah sistematik yang memiliki aturan atau pola. Aturan tersebut dapat dilihat melalui dua hal, yaitu sistem bunyi dan sistem makna. Bahasa juga memiliki sifat yang manasuka, di mana manusia bebas menentukan bahasanya sendiri. Bahasa juga adalah komunikasi, yaitu alat komunikasi. Maka dari itu, bahasa bagi manusia merupakan alat komunikasi untuk mengungkapkan pikiran dan perasaannya melalui bahasa kepada orang lain atau lawan bicaranya. Oleh karena itu, bahasa yang digunakan oleh manusia bermacam-macam, hal tersebut dapat dipengaruhi oleh faktor internal maupun eksternal manusia itu sendiri (Suhardi, 2013:21).

Bahasa adalah alat komunikasi antara anggota masyarakat berupa simbol yang dihasilkan oleh alat ucap manusia. Bahasa mempunyai kaitan yang erat dalam proses komunikasi. Komunikasi pada hakikatnya adalah proses penyampaian pesan dari pengirim 


\section{Mia Nur Aprilia dan Nuryani \\ Universitas Islam Negeri Syarif Hidayatullah Jakarta}

kepada penerima (Prayoga, 2013). Bahasa yang digunakan oleh anak-anak, sampai dengan dewasa memiliki struktur bahasa yang berbeda, mulai dari penguasaan kosa kata hingga penyusunan kata itu sendiri. Bahasa akan berkembang seiring dengan usia penggunanya. Akan tetapi, secara umum perkembangan yang luar biasa terjadi pada saat usia dini. Seperti disampaikan oleh Kusno dalam tulisannya bahwa anak akan mengalami perkembangan pada usia dini, yakni antara usia 0-9 tahun (Kusno, 2017:40). Dengan begitu, pada usia tersebut anak-anak seharusnya mendapatkan asupan yang positif dalam segala hal guna perkembangan yang lebih baik nantinya. Perkembangan tersebut terjadi melalui tahapan yang progresif dan berkesinambungan. Hal tersebut dapat diartikan bahwa perkembangan terjadi dalam diri manusia sejak lahir sampai meninggal.

Perkembangan yang terjadi pada anak salah satunya adalah kemampuan berbahasa. Terdapat empat keterampilan berbahasa yang harus dimiliki oleh setiap manusia, salah satunya merupakan keterampilan berbicara. Kemampuan ini termasuk dalam kemampuan produktif karena dalam berbicara seseorang harus memproduksi suara dan ide yang akan dia sampaikan kepada orang lain (Mulyati, 2019:23). Banyak kegiatan yang masuk dalam kategori keterampilan berbicara yang salah satunya adalah kemampuan bercerita. Kemampuan bercerita pada anak-anak sampai dewasa pun akan berbeda. Pada usia 5 tahun, anak-anak sedang mengalami masa perkenalan dari lingkungan teman-temannya sehingga masih mengikuti kata apapun yang anak dapatkan dari lingkungan tersebut. Hal tersebut tentu saja terkait dengan perkembangan anak baik secara sosial maupun psikologis. Oleh karena itu, dalam menyelidiki atau meneliti kemampuan bercerita anak juga harus melihat kondisi atau konteks psikologis anak. Dengan demikian, kajian yang digunakan dalam penelitian ini adalah kajian psikolinguistik.

Psikolinguistik merupakan studi yang mengkaji hubungan antara bahasa dengan pikiran manusia (Dardjowidjojo, 2010:7). Berbicara tentang minda (mind) tidak pernah ada yang mampu menyelami pikiran manusia. Demikian juga dengan bahasa yang disimpan dalam pikiran manusia terdapat berjuta-juta kata atau bahkan lebih yang tersimpan dalam pikiran manusia. Banyak sekali pemilihan kata yang digunakan oleh manusia, sampai manusia merasa kebingungan akan menggunakan bahasa seperti apa yang akan diujarkan oleh manusia. Dalam pikiran manusia juga tersimpan banyak kata yang bersinonim, sehingga memungkinkan manusia dapat memilih kata yang berbeda dengan makna yang hampir sama. Dengan demikian, dapat dikatakan bahwa sesuatu yang keluar dari pikiran manusia hanya dia sendiri yang mengetahuinya. Ujaran yang dikeluarkan oleh manusia juga berimplikatur dengan pikiran yang sedang dialami oleh manusia (Nuryani dan Dona, 2013:5). Demikian juga yang terjadi pada anak ketika sedang melakukan kegiatan berbahasa yang salah satunya adalah bercerita.

Kemampuan bercerita pada anak usia 5 tahun mendapatkan kalimat-kalimat bahasa yang diucapkan melalui pendengaran pada waktu berkomunikasi dengan ibunya atau dengan orang yang ada di sekitarnya. Kegiatan berbahasa yang dilakukan melalui komunikasi dengan lingkungan, baik lingkungan keluarga maupun lingkungan sosial yang lebih besar akan membuat kemampuan berbahasa anak semakin berkembang. Perkembangan tersebut terjadi secara terus menerus, sistematis, dan progresif sampai menuju pada tingkat kedewasaan. 
Perkembangan yang terjadi menyangkut baik fisik maupun psikis (Yusuf, 2009:5). Oleh karena itu, dalam setiap kegiatan berbahasa pada anak tidak dapat mengabaikan kondisi psikologis anak. Hal yang demikian juga berlaku dalam proses memproduksi kalimat yang juga melibatkan juga psikologi dalam diri anak. Agar anak tersebut mendapatkan ujaran dengan pengucapan yang baik, maka diperlukan keterlibatan organ pengucapan, syaraf-syaraf pendukung, dan kondisi psikologi yang sedang dialami. Maka kemudian terjadilah pemerolehan bahasa yang diujarkan oleh anak tersebut.

Pada tahap paralinguistik, umur 3-5 tahun berada di tahap banyak-kata. Tahap paralinguistik yaitu ketika anak-anak sedang mengeluarkan sejumlah sususan kata dan pada tahap banyak-kata tuturan anak akan lebih panjang dan biasanya lebih teratur. Anak tersebut tidak lagi menggunakan dua kata tetapi menggunakan tiga kata atau lebih. Pada umumnya anak yang berusia 5-6 tahun bahasa anak yang digunakan menyerupai bahasa orang dewasa (Fatmawati, 2015:71). Demikian juga yang terjadi pada subyek penelitian. Berdasarkan pengamatan awal yang dilakukan, subyek penelitian mampu berbicara dengan menggunakan bahasa atau pilihan kata dan penyusunan kalimat seperti layaknya orang dewasa. Meskipun demikian, terdapat keterbatasan-keterbatasan yang memang merupakan kekhasan yang terjadi pada anak-anak usia tersebut.

Bercerita merupakan salah satu kebiasaan yang sudah ada sejak dari dulu. Melalui bercerita, seseorang akan mendapatkan informasi yang baru, menumbuhkan daya nalar, daya ingat, serta kepekaan pendengaran dan imajinasi anak tersebut(Arifia, 2014). Kemampuan bercerita tidak dapat dipisahkan dengan pembelajaran berbicara karena bercerita salah satu teknik dari pembelajaran berbicara. Berbicara memiliki beberapa macam bentuk seperti, berbicara berdasarkan gambar, berbicara berdasarkan rangsang suara, berbicara berdasarkan wawancara, dan berdiskusi. Dengan begitu anak yang sedang bercerita dapat menambah keterampilan berbicara (Lestari, 2018). Anak usia 5 tahun masuk ke dalam periode diferensiasi. Pada periode ini, anak telah menguasai bahasa ibu, dalam arti tata bahasa pokok dari orang dewasa. Fungsi bahasa untuk berkomunikasi mulai berfungsi. Perbendaharaan kata telah berkembang baik secara kuantitaif maupun kualitatif. Persepsi anak dan pengalamannya tentang dunia mulai ingin dibagikannya dengan orang lain (Pujhiastuti dkk, 2013).

Pada penelitian ini, penulis menggunakan objek penelitian anak berusia 5 tahun yang bernama Ahmad Abizar. Ahmad Abizar adalah anak ketiga dari tiga bersaudara dari pasangan suami istri Bapak Komarudin dan Ibu Siti Romlah. Latar belakang keluarga tersebut cukup sederhana dan memadai. Ahmad Abizar lahir di Bogor. Abizar memiliki keutamaan atau keunikan dari anak usia 5 tahun lainnya yaitu seorang anak yang super aktif dalam berbicara di keluarganya atau di lingkungan sekitar. Anak tersebut banyak berbicara sampai kata-kata yang dikeluarkan seperti bahasa orang dewasa. Selain itu, Abizar memiliki tanggapan yang cepat ketika ada sebuah pertanyaan dan Abizar cepat untuk menangkap stimulus bahasa yang ada di lingkungannya, baik melalui media sosial atau lawan tuturnya. Dengan latar belakang orang tua Abizar yang selalu memberikan pengajaran kata-kata yang baik dan bahasa Ibu, sehingga Abizar berbicara sehari-hari menggunakan bahasa Ibu. Karena tingkahnya yang tidak bisa diam, Abizar sering bermain dengan teman-temannya, sehingga banyak faktor yang 
mempengaruhi bahasa yang dia ucapkan selama bercerita. Abizar sudah memiliki bahasa yang cukup baik dan lancar, hanya saja Abizar jika sedang bercerita menggunakan tekanan nada yang kadang emosi, atau pun rendah sesuai perasaan yang sedang dialami.

Penelitian ini bertujuan untuk mengetahui kemampuan bercerita pada anak usia 5 tahun dan bentuk kalimat yang diujarkan oleh anak usia 5 tahun.

\section{METODE PENELITIAN}

Metode yang digunakan dalam penelitian ini metode kualitatif. Metode kualtitatif adalah suatu pendekatan yang berorientasi pada fenomena atau gejala secara alamiah (Susilana, 2014:1). Sumber data yang digunakan yakni rekaman suara seorang anak usia 5 tahun yang bernama Ahmad Abizar. Ia sekolah TK di PAUD Baitussholihin yang beralamat di Villa Permata Mas, Kec. Gn Putri, Kab. Bogor. Teknik pengambilan data dilakukan melalui wawancara atau dialog untuk mengungkapkan kemampuan bercerita pada anak tersebut. Peneliti berusaha untuk mendapatkan respon bercerita si anak dengan cara mengajukan beberapa pertanyaan. Setelah memberikan pertanyaan lalu direkam dengan aplikasi rekaman suara untuk mendapatkan jawaban dari anak tersebut. Hasil rekaman tersebut kemudian ditranskripsi guna mendapatkan data catatan secara tertulis dari subyek penelitian tersebut.

\section{HASIL DAN PEMBAHASAN}

\section{Data 1:}

Kakak : Emang tau dari mana Bizar?

Abizar : Dari Yutup, yutup hp $A$ A. Mana ya hp $A A$ dede mau nonton.

Berdasarkan bahasa yang ujarkan oleh Abizar sudah cukup baik. Bisa dilihat bahwa Abizar merespon pertanyaan Kakanya dengan baik, berarti anak tersebut memahami kalimat yang ditanyakan oleh Kakaknya. Respon yang diberikan oleh subyek penelitian memberikan gambaran bahwa si anak memiliki kemampuan memahami kalimat tanya dengan baik. Untuk memberikan jawaban subyek penelitian juga telah menggunakan kalimat dan pilihan kata secara baik. Subyek memberikan jawaban dengan lebih lanjut bahwa dia mendapatkan tontonan tersebut dari hp yang bukan milik dia sendiri. Abizar mengucapkan kata-kata tersebut sedang menceritakan bahwa dia menemukan sesuatu yang berasal dari youtube.

\section{Data 2:}

Kaka : Ngomong apa?

Abizar : Ihh ngomong, nana yang pas satu kali yang dua kalinya nana ngumpet kan di Umi gini, dede ngeliat, aku ngeliat.

Berdasarkan ujaran di atas, anak mengeluarkan kata-kata dengan nada tinggi.Hal tersebut bisa dilihat dari kata "ih". Hal ini bisa disebabkan oleh bahasa Ibu karena Abizar dari kecil diajarkan bahasa Ibu bahasa Sunda. Tekanan nada seperti itu menunjukkan bahwa tekanan orang Sunda yang sedang marah dan emosi. Ujaran tersebut menunjukkan Abizar ingin meledek kepada temannya bahwa temannya malu dan ingin sembunyi kepada ibunya. 
Subyek penelitian memiliki kemampuan merespon dengan menggunakan kalimat yang panjang. Hal tersebut memberikan pertanda bahwa sebenarnya subyek penelitian mampu memproduksi ujaran dalam bentuk kalimat panjang dengan penguasaan kosa kata yang sudah cukup banyak. Pada usia 5 tahun anak-anak biasanya telah memiliki penguasaan kosa kata dalam jumlah yang banyak. Untuk itu, ketika anak ada orang lain bertanya anak akan secara otomatis mengeluarkan perbendaharaan kata yang selama ini disimpan. Demikian juga dengan subyek penelitian ini yang ternyata telah memiliki banyak perbendaharaan kosa kata sehingga mampu merespon pertanyaan dengan jawaban yang cukup banyak atau kalimat panjang.

\section{Data 3:}

Kaka : Bizar man jadi apa?

Abizar : Mau jadi tentara

Kaka : Kenapa man jadi tentara?

Abizar : Kan ada BOMnya

Berdasarkan ujaran di atas, Abizar menjawab pertanyaan sudah baik dan benar. Hal ini disebabkan karena Abizar memiliki sumber informasi yang luas dengan menjawab "ada bomnya" menunjukkan bahwa Abizar sudah tahu jika menjadi tentara mempunyai BOM. Hal ini dapat diakibatkan dengan faktor media sosial atau lingkungan sekitar.

\section{Data 4:}

Kaka : Gimana de?

Abizar : Seru, ada mainan ikan, ada kereta, ada kuda-kuda, ada kura-kura

Kaka : Bizar di sana ngapain aja?

Abizar : Terus teb di di di pas aku beli tas itu ada ikan di got, ikan gede, ada yang kecil, terus teh aku cemplungin kayu ke got yang ada di kapal, terus teh aku naik. naik eh beli topeng, terus teh sama nempelan si nana.

Berdasarkan ujaran yang disebutkan oleh Abizar, struktur kata yang tidak tepat, dan kata-katanya diulang dengan beberapa kali. Abizar sedang menceritakan bahwa dia senang karena selesai bermain di salah satu tempat wisata. Faktor utamanya karena dia bercerita terlalu cepat, maka kata-kata yang dia keluarkan tidak beraturan. Selain itu, terdapat juga bahasa Ibu pada kata "teh" karena itu menunjukkan penambahan kata pada bahasa Sunda. Dengan demikian, memori yang sedang dialami oleh Abizar merupakan memori jangka panjang karena dia sudah mengingat apa yang pernah dia lakukan.

\section{Data 5:}

Mama : Kenapa dimasukin botol nanti berat?

Abizar : Ga berat, atub kan bannya kempes mulu.

Berdasarkan ujaran di atas, Abizar sudah memasukan kata yang mengandung bahasa Ibu. Hal tersebut bisa dilihat dari penggunaan kata "atuh" yang dikenal merupakan kata tambahan dalam bahasa Sunda. Abizar mengeluarkan ujaran tersebut ketika sedang dinasihati 
oleh Mamanya. Namun, Abizar tidak mendengarkan apa kata Mamanya sehingga dia melawan kata-kata Mamanya. Hal ini bisa disebabkan dari faktor lingkungan atau emosi Abizar. Dengan itu Abizar sedang melakukan hal yang tidak ingin dinasihati oleh siapa pun.

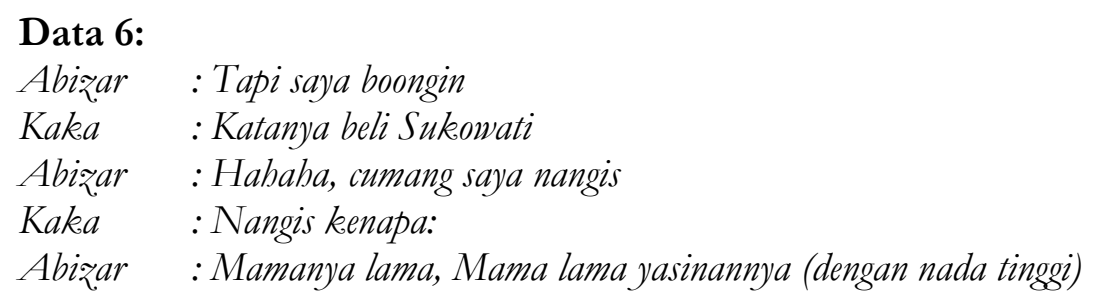

Berdasarkan ujaran yang diucapkan oleh Abizar menggunakan bahasa baku, dengan kata "saya" yang biasanya anak tersebut memakai kata panggilan "aku" tetapi pada ujaran tersebut memakai kata "saya". Abizar menggunakan kata "saya" setelah mengikuti mamanya ngaji yasin. Hal ini bisa disebabkan faktor lingkungan yang dia dapatkan di tempat pengajian, dan dia ingin memberitahukan bahwa dia menangis saat mamanya sedang pengajian. Terdapat kosa kata yang tidak tepat pada kata "cumang" harusnya "cuman". Hal ini bisa disebabkan oleh faktor lingkungan juga atau bahasa Ibu yang diperoleh. Pada ujaran terakhir Abizar mengucapkannya dengan intonasi yang tinggi, karena Abizar sedang mengalami sikap yang emosional dan kesal sehingga nada berbicaranya sangat tinggi.

\section{SIMPULAN}

Berdasarkan pembahasan yang telah dilakukan dapat disimpulkan bahwa subyek penelitian memiliki kemampuan bercerita yang cukup bagus. Hal tersebut terlihat dari pola kalimat yang digunakan dalam bertutur. Subyek penelitian terlihat menggunakan kalimat yang memiliki pola yang utuh. Selain itu, dalam pemilihan kata (diksi) subyek penelitan juga cenderung memilih kata yang formal dan semi formal. Subyek penelitian juga telah mampu memberikan respon yang baik terhadap setaip pertanyaan yang diberikan. Dengan demikian dapat dikatakan bahwa pemerolehan bahasa yang diperoleh Ahmad Abizar yang berusia 5 tahun memiliki bahasa yang sudah cukup baik, seperti orang dewasa. Hal tersebut dipengaruhi oleh faktor lingkungan dan B1 yang digunakan oleh subyek penelitian dalam kehidupan sehari-hari.

\section{UCAPAN TERIMA KASIH}

Saya ucapkan terima kasih kepada pihak yang telah mendukung penelitian saya tersebut. Terutama untuk Dosen Pengampu mata kuliah Psikolinguistik yaitu Dr. Nuryani, S.Pd., M.A. Karena bimbingan beliau saya dapat menulis penelitian ini dengan mengetahui teori-teori yang bersangkutan dengan psikolinguistik. Terima kasih untuk jurnal-jurnal di google yang telah membantuk saya untuk mendapatkan referensi sehingga menghasilkan sebuah penelitian. Terima kasih juga untuk Ahmad Abizar yang telah membantu saya menjadi data untuk penelitian ini dengan merekam suara Abizar.

\section{DAFTAR PUSTAKA}


Arifia Bella Dina. (2014). "Peningkatan Keterampilan Bercerita Ekspresif Anak Usia 5-6 Tahun Dengan Role Playing Di TK Arum Puspita Triharjo Pandak Bantul”. Yogyakarta: UNY.

Dardjowidjojo, Soejono. (2010). Psikolinguistik Pengantar Pemahaman Bahasa Manusia. Jakarta: Yayasan Obot Indonesia.

Fatmawati Suci Rani. (2015). "Pemerolehan Bahasa Petama Anak Menurut Tinjauan Psikolinguistik". Jurnal Lentera Vol. XVIII No. 1, Juni 2015.

Kusno, Ali. (2017). "Perkembangan Fungsi Pragmatik pada Anak Usia 2,5 Tahun (Studi Kasus pada Azza Aqila Jihan Syuasabitha)", Jumal Kadera Bahasa, Volume 9, Nomor 1, Edisi April 2017

Lestari Ika. (2018). “Analisis Awal Kemampuan Bercerita Pada Anak Usia 5-6 Tahun”. Jurnal Ilmiah dan Dikmas Vol. 13 No. 2 Desember 2018.

Lisnawati Iis. (2008). "Psikolinguistik dalam Pembelajaran Bahasa". Educare Jurnal Pendidikan dan Budaya Vol. 6 No. 1 Agustus 2008.

Mulyati, Yeti., dkk. (2019). Bahasa Indonesia, Tangerang Selatan: Penerbit Universitas Terbuka, Cetakan ke-20.

Nuryani dan Dona Aji Karunia Putra. (2013). Psikolinguistik. Tangerang Selatan: Mazhab Ciputat.

Prayoga Yoekie Aditya. (2010). "Kemampuan Bercerita Siswa Usia 7-8 Tahun Berdasarkan Klasifikasi Kalimat Bahasa Indonesia di SDN Kalijudan Kecamatan Mulyorejo Surabaya”. Skriptorium Jurnal Unair Vol. 1 No. 2.

Pujihastuti Etin, dkk. (2013). "Pengungkapan Kegembiraan Pada Anak Usia 3-5 Tahun Dalam Kajian Psikolinguistik". Universitas Jenderal Soedirman Purwokerto.

Suhardi. (2013). Pengantar Linguistik Umum. Jogjakarta: Ar-ruzz Media.

Susilana Rudi. (2014). "Penelitian Kualitatif”. Jurusan Kurikulum dan Teknologi Pendidikan UPI.

Yusuf, S. (2009). Psikologi Perkembangan Anak \& Remaja. Bandung: Remaja Rosdakarya. 